\title{
The Role of International Law in Protection against Attacks on Children's Education Rights in Armed Conflict
}

\author{
Khalil Akbariavaz ${ }^{1} \&$ Pardis Moslemzadeh Tehrani ${ }^{2,3}$ \\ ${ }^{1}$ University of Malaya, Malaysia \\ ${ }^{2}$ Faculty of Law, University of Malaya, Malaysia \\ ${ }^{3}$ Deputy Editor of the University Malaya Journal of Law and Policy (UMJLP), University of Malaya, Malaysia \\ Correspondence: Khalil Akbariavaz, University of Malaya, Malaysia. E-mail: tafakor.kh@gmail.com
}

Received: May 10, 2020

doi:10.5539/jpl.v13n3p90
Accepted: June 16, $2020 \quad$ Online Published: August 17, 2020

URL: https://doi.org/10.5539/jpl.v13n3p90

\begin{abstract}
This study was aimed to investigate issues associated with the education rights of children in international and non-international armed conflict and the influence of armed conflict on educational staff and facilities in war-torn countries. Relevant international conventions are reviewed to evaluate their effectiveness in curbing the influence of armed conflict on children's education. The study highlights the importance of international humanitarian law (IHL) in inhibiting attacks against students, educational staff, and educational facilities during armed conflict. It also reviews conventional and non-conventional methods of protection and suggests ways in which IHL may be clarified and developed to enhance the supervision of the provision of education during armed struggles. The article concludes that it is necessary to have specific international conventions, oversight bodies and relevant educational obligations in order to guarantee law enforcement and require countries or member states to implement articles or provisions properly so as to improve and reinforce the education rights of children whose lives are impacted by armed conflict. In emergency situations, legal provisions constitute a vital protective measure.
\end{abstract}

Keywords: international humanitrian law, children, education, armed conflict

\section{Introduction}

Contemporary armed conflict at the international and non-international level sometimes deliberately targets civilians, and aggression is often an element of warfare and its strategies. The forms of violence currently being assumed by armed conflict and the utilization of sophisticated weapons in combat has resulted in an enhancement in the number of victims in civilian populations, especially children. ${ }^{1}$. Armed conflict has a significant impact on children and hinders their development as a result of the closure of schools, interruptions to education, insecurity, concomitant psychological effects and more. These circumstances have a very deep effect on children ${ }^{2}$. In 2014, the United Nations Educational, Scientific and Cultural Organization (UNESCO) noted that children in countries such as Congo, Egypt, Palestine, Nigeria, Philippines, South Sudan, Syria, Turkey, and Yemen were influenced by conflict, with 28.5 million children out of school in those states combined ${ }^{3}$.

Education is a significant element of human capital and is considered a 'multiplier right'. Armed conflicts destroy private and public infrastructure, which affects children's education ${ }^{4}$. International law, human rights law, criminal law and humanitarian law have different conventions and resolutions which may be applied to the examination of this situation. For instance, Article 4, Paragraph 3 (a), of Additional Protocol II to the Geneva Conventions states in respect of children that "they shall receive an education, including religious and moral education, in keeping with the wishes of their parents, or in the absence of parents, of those responsible for their care"5. In practice,

\footnotetext{
1 'The Evolution of Warfare The Evolution of Warfare', International Review of the Red Cross, 97.900 (2015) <https://doi.org/doi:10.1017/S1816383116000497>; ICRC, 'The Law of Armed Conflict Conduct of Operations', $2002,9$.

${ }^{2}$ Max Baldwin Orero and others, The Impact of Conflict on the Intergenerational Transmission of Chronic Poverty: An Overview and Annotated Bibliography, CPRC, $2011<\mathrm{https}$ ://doi.org/10.2139/ssrn.1753025>.

${ }^{3}$ Susan Nicolai and Sébastien Hine, 'Investment for Education in Emergencies: A Review of Evidence', $2015,15$.

${ }^{4}$ Rzeszut and Shanks Barakat, Connolly, Hardman, Lewis, Lineker, Menkhaus, 'Beyond Fragility: A Conflict and Education Analysis of the Somali Context', 2014, 3; Mario Novelli and Alan Smith, 'The Role of Education in Peacebuilding', $2011,28$.

5 Article 4 paragraph 3 (a), 'Additional Protocol II', 1977.
} 
however, there are several obstacles to the realization of the right to education during armed conflict ${ }^{6}$.

Gender-related violence, lack of teachers, and lack of finances for education are specific barriers and challenges for children in armed conflict that may prevent full implementation of their right to education and create contexts engendering violations ${ }^{7}$. International humanitarian law contains provisions directed towards the legal protection of students, educational staff, and educational facilities in armed conflict. Additional Protocol I in Article 77(1) notes that "Children shall be the object of special respect and shall be protected against any form of ... assault. The Parties to the conflict shall provide them with the care and aid they require, whether because of their age or for any other reason" 8 . Article 8 of the Rome Statutes of the International Criminal Court (ICC) prohibits "Intentionally directing attacks against buildings dedicated to ... education ... provided they are not military objectives". Attacks on students, educational staff, and educational facilities in armed conflict are prohibited ${ }^{9}$.

This investigation concentrates on the causes and influences of violations of children's education rights during armed conflict. It highlights conditions leading to such violations in particular societies, seeks to estimate the magnitude of the violations and the damage done to educational structures and provides international evidence through global literature reviews of attacks on students, educational staff, and educational facilities in conflictaffected areas during armed conflict to arrive at findings. Finally, it considers challenges in the field of children's education rights during periods of armed conflict.

\section{Background}

Disruptions affect children more seriously than adults ${ }^{10}$. An adult who is displaced, loses employment, is malnourished, or is ill-treated during armed conflict may continue his life normally later. A child in the same situation may suffer from permanent stunting of physical and mental development ${ }^{11}$. A child lacking access to the school during displacement may be incapable of regaining the chance and may thus be deprived of future opportunities. Children thus require different types of protection ${ }^{12}$.

In Western Europe, before the Enlightenment, education was provided for by private delegation. Following revolutions in France and the United States, education became a democratic attitude and the provision of education became a state duty ${ }^{13}$. After World War I, in 1920, the Children's Fund was prearranged around the International Save the Children Union (ISCU) under the patronage of the International Committee of the Red Cross (ICRC) ${ }^{14}$. The League of Nations accepted the first edition of the Declaration of the Rights of the Child, also known as the Geneva Declaration of the Rights of the Child, in $1924^{15}$. The Declaration of 1924 does not clearly mention the right of children to education; however, this declaration recognized some distinctive rights of children ${ }^{16}$.

Following the Second World War, the plight of Europe's children was grave ${ }^{17}$. The United Nations (UN) in 1946 formed a new agency to provide food, clothing, and health care for them. In 1953, the United National International Children's Emergency Fund (UNICEF) became a permanent part of the United Nations ${ }^{18}$. In 1959, the UN General

\footnotetext{
${ }^{6}$ UNESCO, 'UNESCO Education Strategy 2014-2021', 2014, 19.

${ }^{7}$ Unicef, A Human Rights-Based Approach to Education for All, 2007; Patricia Justino, 'Barriers To Education in Conflict-Affected Countries and Policy Opportunities', 2015, 1-12.

${ }^{8}$ Article 77(1), Additional Protocol I, 1977.

${ }^{9}$ Article 8, 'Rome Statute of the International Criminal Court', 1998.

${ }^{10}$ Rebecca C. Fauth, Lucinda Platt, and Samantha Parsons, 'The Development of Behavior Problems among Disabled and Non-Disabled Children in England', Journal of Applied Developmental Psychology, 52.June 2016 (2017), 50<https://doi.org/10.1016/j.appdev.2017.06.008>

${ }^{11}$ United Nations, 'Armed Conflicts and Their Consequences', 1999, p.205<http://www.un.org/esa/socdev/rwss/docs/2001/15 Armed Conflict.pdf>; International Committee of the Red Cross ICRC, 'Protection of Victims of Armed Conflict through Respect of International Humanitarian Law', $1999<\mathrm{https://www.icrc.org/eng/resources/documents/misc/57jpzn.htm>.}$

${ }^{12}$ UNICEF, The State of the World's Children 2016, United Nations Children's Fund, $2016<\mathrm{https}: / / \mathrm{doi} .0 \mathrm{gr} / 10.18356 / 4 \mathrm{fb} 40 \mathrm{cfa}-\mathrm{en}>$.

13 Encyclopædia britannica, 'Western Education In The 19th Century', $2018<$ https://www.britannica.com/topic/education/Westerneducation-in-the-19th-century>.

14 Daniel Palmieri, 'The International Committee of the Red Cross in the First World War', ICRC, 2014 $<$ https://www.icrc.org/en/document/international-committee-red-cross-first-world-war-0>.

${ }^{15}$ Wikipedia, 'Children's Rights Movement', $2018<\mathrm{https}$ ://en.wikipedia.org/wiki/Children\%27s_rights_movement>.

${ }^{16}$ University of Pretoria, 'Chapter 2 the right to education and other human', 2001, 32.

17 Christian Habbe, 'A Time of Retribution Paying with Life and Limb for the Crimes of Nazi Germany', 2011 $<\mathrm{http} / /$ www.spiegel.de/international/germany/a-time-of-retribution-paying-with-life-and-limb-for-the-crimes-of-nazi-germany-a759737.html>.

18 humanity development library 2.0, 'The NGLS Handbook of UN Agencies, Programmes and Funds Working For', 2018 $<$ http://www.nzdl.org/gsdlmod?e=d-00000-00---off-0hdl--00-0----0-10-0---0---0direct-10---4-------0-11--11-en-50---20-about---00-0-1-00-04----0-0-11-10-0utfZz-8-00\&cl=CL1.12\&d=HASHbcccd898c59e7e41e02150\&gt=2>.
} 
Assembly approved the Declaration of the Rights of the Child, which covers health care, education, shelter, and good nutrition. ${ }^{19}$. UNESCO champions quality education globally and asserts that education has a necessary role to play in human, social, and economic development ${ }^{20}$. Armed conflicts gradually target children and educational infrastructure ${ }^{21}$. Nevertheless, conflicting states are obliged to guarantee the right of children to education ${ }^{22}$. Every society has an interest in children's education, regardless of country, sex, or circumstances of birth ${ }^{23}$. States are obliged to fulfill the basic minimum obligations of the right to education and to guarantee equal access to educational programs. When states are incapable to fulfil their obligations, other actors such as the UN, nongovernmental organizations, and other states may be capable to assist in the realization or facilitation of education rights ${ }^{24}$.

Child education rights have been established via human rights declarations and conventions. ${ }^{25}$ The Universal Declaration of Human Rights (UDHR) adopted in 1948 has passages associated with education. Article $26^{26}$, which was added in 1947, maintains the concept of compulsory basic education ${ }^{27}$. It notes that education should strengthen respect for human rights and promote peace and notes that parents may choose their child's education type $^{28}$. This underlies UNESCO conventions regarding child education and provides the foundations for the moral and legal education principles committed to by states ${ }^{29}$. In 1951, UNESCO affirmed universal compulsory education $^{30}$. It also stated the addition of the right of parents to choose education to the Universal Declaration to achieve balance $^{31}$. In 1959, Principle 7 of the United Nations Declaration of the Rights of the Child noted that "the child is entitled to receive education, which shall be free and compulsory at least in the elementary stage"

A contract to forbid discrimination in education was adopted before the right to education was documented in international covenants by the UNESCO Convention against Discrimination in Education (1960) ${ }^{33}$. Article 4 of the Convention reports that State parties shall "make primary education free and compulsory" and make other levels of education universally available. Nonetheless, children's rights are violated or ignored in ways unlike those of adult rights. As a result, protections against systematic discrimination against children are particularly important in the realization of education rights ${ }^{34}$. Besides, the Convention definitely guarantees the protection of the rights of national minorities. The provision of non-discriminatory education means that States must command "equality of opportunity and treatment for all in education". This article supports equality of educational opportunities regardless of race, gender, and other discrimination ${ }^{35}$. Also, Article 2 of the UDHR (1948) sets out the simple

\footnotetext{
${ }^{19}$ United Nations General Assembly, 'Convention on the Rights of the Child Convention on the Rights', Treaty Ser.September (2013), 3 $<$ https://doi.org/10.1177/0907568213481816>.

${ }^{20}$ Unesco, 'UNESCO and Education: “ Everyone Has the Right to Education ”, United Nations Educational, 2011, 6.

${ }^{21}$ Joseph Nhan-O’Reilly, 'Delivering Education to Children Affected by the Conflict in Syria', Golobal Partnership for Education, 2016 $<$ https://www.globalpartnership.org/blog/delivering-education-children-affected-conflict-syria>.

${ }^{22}$ United Nations, 'Effective Protection of Civilians in Armed Conflict Requires', $2005<\mathrm{https} / /$ www.un.org/press/en/2005/sc8575.doc.htm>.

${ }^{23}$ Human Rights Watch, 'The Education Deficit Failures to Protect and Fulfill the Right to Education through Global Development Agendas', $2016<$ https:/www.hrw.org/report/2016/06/09/education-deficit/failures-protect-and-fulfill-right-education-through-global>.

${ }^{24}$ Human Rights Watch, 'The Education Deficit Failures to Protect and Fulfill the Right to Education through Global Development Agendas', 2016.

${ }^{25}$ UNICEF, The state of the world' $s$ children Celebrating 20 Years of the Convention on the Rights of the Child, 2009 $<$ http://www.unicef.org/rightsite/sowc/fullreport.php>.

${ }^{26}$ Article 26, "Everyone has ]the right to education. Education shall be free, at least in the elementary and fundamental stages. Elementary education shall be compulsory. Technical and professional education shall be made generally available and higher education shall be equally accessible to all based on merit" 'Universal Declaration of Human Rights', 1948.

${ }^{27}$ UNESCO, 'Operational Definition of Basic Education', 2007, 6-13.

${ }^{28}$ Yves Daudet and Kishore Singh, 'The Right to Education: An Analysis of UNESCO\&apos;s Standard-Setting Instruments', 2001, 67
} $<$ http://unesdoc.unesco.org/images/0012/001238/123817e.pdf>.

29 Richard Pierre Claude, 'The Right to Education and Human Rights Education', Scielo, 2005 $<$ https://doi.org/http://dx.doi.org/10.1590/S1806-64452005000100003>.

${ }^{30}$ Norrag SPECIAL ISSUE, 'The Right to Education Movements and Policies : Promises and Realities', $2017,52$.

31 John Adeboye Adeyemo, 'The Demand for Higher Education and Employment Opportunities in Nigeria', 2018 $<$ https://books.openedition.org/ifra/1024>.

${ }^{32}$ principle 7 the united Nations, 'Declaration of the Rights of the Child', 1959.

${ }^{33}$ Birute Praneviciene and Aurelija Puraite, 'Right To Education in International Legal', 6195.121 (2010), 142.

${ }^{34}$ University of minnesota Human rights Library, 'Report of the World Conference Against Racism, Racial Discrimination, Xenophobia and Related Intolerance', $2001<\mathrm{http}$ :/hrlibrary.umn.edu/instree/wcardeclaration.html $>$.

${ }^{35}$ United Nations Educational, 'Convention against Discrimination in Education Adopted by the General Conference at Its Eleventh Session ', 1960. 
necessities for non-discrimination in education ${ }^{36}$.

The right to education provided by the International Covenant on Human Rights is officially binding with the adoption of the International Covenant on Economic, Social, and Cultural Rights (1966). In Article 13, Paragraph 2, the Covenant reports: "Primary education shall be compulsory and available free to all" ${ }^{37}$. This provision is according to the freedom of parents to select their children's education in line with the minimum standards of education, which is confirmed by the ICESCR ${ }^{38}$. Therefore, Article 18(4) of the ICCPR reports: "States Parties to the present Covenant undertake to respect the liberty of parents and, when applicable, legal guardians to ensure the religious and moral education of their children in conformity with their own convictions" ${ }^{\prime 39}$. The right to education provided for here reiterates that everyone has this right and consequently that primary education must be obligatory and accessible free to all ${ }^{40}$. The Convention on the Rights of the Child (CRC) of 1989 guarantees the right of the child to education and sets out rules in this regard. Article 24 denotes a clear commitment to the principle of inclusive education as a goal. Article 29 (1) sets out the goals and objectives of education, stating that education should help to develop the personality, talent, and physical and mental capabilities of children.

International humanitarian law, contrasting human rights, does not set out a "right to education", but many of its provisions are meant to ensure the protection of students, education personnel, and educational facilities during armed conflict via specific Acts. The obligations of the parties involved in hostilities are set out in international humanitarian law. This suggests that it is important to maintain education during armed conflict ${ }^{41}$. Armed conflicts arise from a lack of respect for international humanitarian law and have grave impacts on children's education. They are a noteworthy impediment to achieving the aims of Education for All (EFA) set out by the international community in 1990 in the Jomtien Declaration, which is limited to emergency education in armed conflict. The goal was to guarantee universal access to basic education for all children. Unfortunately, in recent international and non-international conflicts, this has not been implemented ${ }^{42}$.

The protection of child education rights was affirmed in both the Fourth Geneva Convention of 1949 and the Additional Protocols of 1977. Article 24 of the Fourth Geneva Convention (1949) guarantees child rights to education, affirming they are the most vulnerable group during armed conflict ${ }^{43}$. It obliges State parties to armed conflict to ensure that children under the age of 15 orphaned or separated from their families by war are not neglected ${ }^{44}$. It further affirms the right of arrested children to continue their studies as follows: "All possible facilities shall be granted to internees to continue their studies or to take up new subjects. The education of children and young people shall be ensured; they shall be allowed to attend schools either within the place of internment or outside" ${ }^{45}$. This is in line with Article 142 of the Fourth Geneva Convention, which mandates "facilities for visiting protected persons and for distributing relief supplies and materials from any source intended for educational, recreational or religious purposes" ${ }^{\prime 4}$.

Article 77 of Additional Protocol I highlights that "Children shall be the object of special respect and shall be protected against any form of indecent assault. The Parties to the conflict shall provide them with the care and aid

\footnotetext{
${ }^{36}$ Article 2, "Everyone is entitled to all the rights and freedom set forth in this declaration without distinction of and kind such as race, color, sex, language and religion” 'UDHR', 1948.

${ }^{37}$ ICESCR, 'International Covenant on Economic, Social and Cultural Rights', PWEsCR (Programme on Women's Economic, Social and Cultural Rights), 2015, $21<\mathrm{https://doi.org/10.1177/096701067700800312>;} \mathrm{Article} \mathrm{13,} \mathrm{'International} \mathrm{Covenant} \mathrm{on} \mathrm{Economic,} \mathrm{Social} \mathrm{and}$ Cultural Rights', 1966.

38 Felix Morka, 'The Right to Education Using Module 16 in a Training Program', 2018 $<$ http://hrlibrary.umn.edu/edumat/IHRIP/circle/modules/module16.htm>.

39 Article 18, International Covenant on Economic, Social and Cultural Rights, 1966.

40 Australian Human rights Commission, 'Freedom of Thought, Conscience and Religion or Belief', 2018 $<$ https://www.humanrights.gov.au/freedom-thought-conscience-and-religion-or-belief $>$.

${ }^{41}$ ICRC, 'Framework for Access to Education Contents', 2018, 5.

42 EFA Global Monitoring Report team, EFA Global Monitoring Report: Education For All 2000-2015: Achievements and Challenges, 2015; Carol Bellamy, 'The State of the World's Children 1999: Education.', Unicef, 1999, p. 130.

${ }^{43}$ Article 24, "The Parties to the conflict shall take the necessary measures to ensure that children under fifteen, who are orphaned or are separated from their families as a result of the war, are not left to their own resources, and that their maintenance, the exercise of their religion and their education are facilitated in all circumstances. Their education shall, as far as possible, be entrusted to persons of a similar cultural tradition" 'The Fourth Geneva Convention of 1949'.

44 CarolynTabatha Abu El-Haj Hamilton, 'Armed Conflict: The Protection of Children Under International Law' $<$ https://www1.essex.ac.uk/armedcon/story_id/000577.html >.

45 Article 94, 'The Fourth Geneva Convention of 1949'.

${ }^{46}$ Article 142, The Fourth Geneva Convention of 1949.
} 
they require, whether because of their age or for any other reason"47. This provides distinctive protection for children involved in an international armed conflict beyond that provided by customary international law. Though the Article does not mention education clearly, it emphasizes the necessity to provide the required facilities for the natural growth of children as far as probable in armed conflict ${ }^{48}$. Article 48 of Additional Protocol I provides a basic assurance of general protection against the impacts of warfare by declaring "the Parties to the conflict shall at all times distinguish between the civilian population and combatants and between civilian objects and military objectives and accordingly, shall direct their operations only against military objectives" ${ }^{\text {"49 }}$. According to this, humanitarian principles governing the conduct of combatants have been proven to protect civilians from harm during military operations ${ }^{50}$. Students, education personnel, and educational facilities are secure by the principle of distinction as they fall under the description of civilians and civilian objects ${ }^{51}$.

Article 58 (c) of the Geneva Convention Protocol Additional I, Protection Against the Effects of Attacks, states that States must take "necessary precautions to protect the civilian population, individual civilians and civilian objects under their control against the dangers resulting from military operations" 52 . The observance of these principles provides general protection to children from the dangers of fighting. Such protection is seriously needed since based on reliable sources, one million children have been orphaned or separated from their families, twelve million left homeless, and two million killed in the past decade alone ${ }^{53}$. Article 78, Paragraph 2, of Additional Protocol I assures the right of education for children in times of armed conflict by declaring that "Whenever an evacuation occurs pursuant to paragraph 1 , each child's education, including his religious and moral education as his parent's desire, shall be provided while he is away with the greatest possible continuity" ${ }^{\prime 4}$. Child education rights also relate to situations of non-international armed conflict. Article 4, Paragraph 3(a) of Additional Protocol II contains an obligation for parties to such conflicts to provide care and help to children since they are in specific need of getting an education, including religious and moral education ${ }^{55}$. Based on the International Criminal Tribunal for the former Yugoslavia (ICTY), in some places there was a purposeful killing of students and teachers, as well as attacks on educational facilities. Another case is that of the Israeli West Bank barrier. The International Court of Justice (ICJ) in 1994 condemned, among other things, “...the restricted access to water, food, education, and health care".

\section{Education Rights under Occupation}

The protection of education in occupied territory is provided for under the standards of international humanitarian ${ }^{l a w^{56}}$. The obligations of occupying powers are determined by the Hague Regulations. Although the provisions of the Hague Regulations do not clearly mention the protection of civilians in national education ${ }^{57}$, the protection of the civilian population essentially suggests the recognition of the right of civilians to go about their regular lives and to continue in essential and customary national education activities. This flows from the obligation of the occupying power to continue the natural administration of the occupied territory, which includes guaranteeing the arranged functioning of educational institutions. The international community has tried to express this right explicitly, particularly for children ${ }^{58}$. In 1939, the International Committee of the Red Cross (ICRC) drafted a

\footnotetext{
47 Article 77, Additional Protocol I 1977.

48 Sobhi Tawil, 'International Humanitarian Law and Basic Education', 2000 $<$ https://www.icrc.org/eng/resources/documents/article/other/57jqq4.htm>; ICRC, 'Study Rule 135' <https://ihl-databases.icrc.org/customaryihl/eng/docs/v1_rul_rule135>.

${ }^{49}$ Article 48, 'Additional Protocol I of 1977'.

${ }^{50}$ Camilla Waszink, 'Protection of Civilians under International Humanitarian Law : Trends and Challenges 1', 2011, 6.

${ }^{51}$ Nathalie Durhin, 'Protecting Civilians in Urban Areas: A Military Perspective on the Application of International Humanitarian Law', International Review of the Red Cross, 98.901 (2016), $182<\mathrm{https}$ ://doi.org/10.1017/S1816383117000029>.

52 Article 58 (c), 'The Geneva Convention Protocol Additional I', 1977.

${ }^{53}$ UNICEF Annual Reports From, 1999.

${ }^{54}$ Article 78, paragraph 2, Additional Protocol I, 1977.

${ }^{55}$ Summary of Article 4, paragraph 3 (a), 'Additional Protocol II', 1949.

56 Albert Camus, 'Occupied Territory', Law, The Practical Guide to Humanitarian, $2018<$ https://guide-humanitarianlaw.org/content/article/3/occupied-territory/>.

57 International Committee of the Red Cross, 'Occupation and Other Forms of Administration of Foreign Territory', 2012, 56 $<$ https://doi.org/10.1017/S1816383112000690>.

${ }^{58}$ International Committee of the Red Cross ICRC, 'Occupation and International Humanitarian Law: Questions and Answers', 2004 $<$ https://www.icrc.org/eng/resources/documents/misc/634kfc.htm>; Hamada Zahawi, 'Redefining the Laws of Occupation in the Wake of Operation Iraqi “Freedom”, California Law Review, 95.6 (2007), 2308.
} 
convention for the protection, care and education of children in occupied territories in the event of armed conflict ${ }^{59}$.

The suffering of children under occupation is well recognized. Innocent children have been exposed to occurrences of war and human rights abuses, orphaned, made homeless without families or guardians to guide them and defend their interests, exiled or forced to labor in the service of occupying forces ${ }^{60}$. The UN Special Report on the Right to Education reported that "military occupations are another appreciable curb on the right to education" 61 . Article 50 of the Fourth Geneva Convention on the Protection of Civilians has distinctive reference to the care and education of children in occupied territories, noting "The Occupying Power shall, with the cooperation of the national and local authorities, facilitate the proper working of all institutions devoted to the care and education of children" 62 . Occupying authorities are therefore obligatory to cooperate with national and local authorities to accomplish these facilities and assist officials in the presentation of their duties. The same article states that occupation authorities are required to implement Article 50 for the benefit of children in occupied territories ${ }^{63}$.

Education is a basic right and is definitely stated in Article 58 of the Fourth Geneva Convention, which states that occupying powers shall accept consignments of books and articles essential for education requirements and shall facilitate their distribution in occupied territory ${ }^{64}$. In addition, based on Article 56 of the Hague Convention, "All seizure of, or destruction or willful damage done to [educational and other] institutions is forbidden, and should be made the subject of legal proceedings" ${ }^{\prime 65}$. Annihilating and destroying educational facilities is forbidden. Education rights of children under occupation are of exceptional significance as they have significant influences on children as vulnerable groups ${ }^{66}$.

\section{Education Rights in Non-International Armed Conflict}

In the late 20th century, extensive state collapse and trade in weapons of mass destruction started. Noninternational armed conflict became grounds for loss of security and human tranquility. In Africa alone, there have been more than 30 wars since 1970, and most of them have been internal. These wars accounted for more than $50 \%$ of the world's deaths in 1996. The ethnic cleansing of the former Yugoslavia, the massacre of people in Sierra Leone, destruction of rebellious militias in East Timor and slaughter of children in Rwanda in 1994 has been estimated at one quarter million ${ }^{67}$. In these difficult situations, it is vital to observe the obligations imposed by Article 3 of the four Geneva Conventions and to implement the provisions of Protocol II of 1977 on noninternational armed conflicts. Such observation would tend towards greater security for children ${ }^{68}$.

Additional Protocol II, Article 4(3) reports that: "children shall be provided with the care and aid they require" 69 . Although the protocol does not reference education explicitly, its focus on the provision of care to children suggests the protection of education rights during non-international conflicts. Article 24 of the Fourth Geneva Convention (1949) promises child education rights during the non-international armed conflict by noting that "The Parties to the conflict shall take necessary measures to ensure that children under fifteen who are orphaned or separated from their families as a result of war are not left to their own resources, and that their maintenance, religion and education are facilitated in all circumstances. Their education shall, as far as possible, be entrusted to persons of a similar cultural tradition" ${ }^{70}$. This Article aims to preserve the education and identity of the children and defend their links

\footnotetext{
${ }^{59}$ Geraldine Van Bueren, 'The International Legal Protection of Children in Armed Conflicts', Cambridge University Press, 43, No. 4 (1994), 809-826.

${ }^{60}$ Save the Children International, 'The War on Children: Time to End Grave Violations against Children in Armed Conflict', 2018, 23-28 $<\mathrm{https}: / /$ www.savethechildren.net/waronchildren/pdf/waronchildren.pdf $>$.

${ }^{61}$ UNICEF, 'Occupied Palestinian Territory', $2006<\mathrm{http}: / /$ www.unicef.org/oPt/Gaza_statistics_27_July_2006_Eng.pdf $>$.

${ }_{62}$ Article 50, The Fourth Geneva Convention, 1949.

${ }^{63}$ Michael J. Dennis, 'Application of Human Rights Treaties Extraterritorially in Times of Armed Conflict and Military Occupation', Cambridge University Press, 99, No. 1 (2005), 131.

${ }^{64}$ Article 58, 'The Fourth Geneva Convention', 1949.

${ }^{65}$ Article 56, 'The Hague Convention 4', 1907.

${ }^{66}$ Manenti Ambrogio and others, 'Report of a Field Assessment of Health Conditions in the Occupied Palestinian Territory', $2016,21$.

${ }^{67}$ Niyonkuru Fulgence, 'War on Terrorism in Africa: A Challenge for Regional Integration and Cooperation Organizations in Eastern and Western Africa', Political Sciences \& Public Affairs, 2015; Uncief, 'The State of the World's Children', 2000, 26-30.

68 International Committee of the Red Cross, 'International Humanitarian Law - Answers to Your Questions', 2014,19 $<$ https://www.icrc.org/eng/assets/files/other/icrc-002-0703.pdf>.

${ }^{69}$ Article 4(3), Additional Protocol II, 1977.

7024
} 
with their roots ${ }^{71}$.

\section{Efforts of International Organizations}

Article 17 (1) of the African Charter on Human Rights (1986) regarding the right to education reports that: "Every individual shall have the right to education"72. Article 11 of the African Charter on the Rights and Welfare of the Child 1990 offers "free and compulsory basic education" and highlights measures such as "equal access to education" for all children ${ }^{73}$. It further notes that education must encourage "African morals, traditional values and cultures, national independence, territorial integrity, unity and solidarity" "74. This Charter offers a practical standard for assessing the realization of the right to education.

The right to education is also preserved in the American Declaration on Human Rights and Duties of Man. Article 31 of that declaration notes that "it is the right of every person to acquire at least an elementary education" 75 . The American Convention on Human Rights (1969) also considers the right and duty of parents to offer education to their children ${ }^{76}$. The significance attached by this Convention to education recommends that Member States should consider education as one of the most essential means for achieving the goals and objectives of the Organization of American States ${ }^{77}$. In the framework of the European Convention on Human Rights (1953), Article 15 of the European Convention on Human Rights specifies that member states should detail the right to education during armed conflict ${ }^{78}$.

In the Arab context, the right to education and other rights essential for the realization of this right are secured by the standards and mechanisms of the League of Arab States and the Organization of the Islamic Conference ${ }^{79}$. The Arab Charter on Human Rights distinguishes the right to education, specifying that "eradication of illiteracy is a binding obligation upon States and everyone has the right to education" 80 . It highlights that education is compulsory and must be free of discrimination by noting that "all forms and levels of primary education shall be compulsory and accessible to all without discrimination of any kind" ${ }^{\prime \prime}$. The Contract on the Rights of Education for Children in Islam was accepted by the Organization of the Islamic Conference in 2005. Article 12 confirms that every child has a right to free compulsory basic education to allow him or her to contribute fully in society ${ }^{82}$. The article notes that the State must offer free primary education to all children and gradually extend this to free secondary education. Article 16 offers special protection for children at risk, such as children with disabilities or special requirements ${ }^{83}$.

\section{Impact of Conflict on Children's Education}

Contemporary armed conflict often targets civilians. The forms of violence, sophisticated weapons and intentional strategies currently used have led to an increase in civilian and child victims. Millions of children have been killed, disabled and injured as a result of armed conflict in this century alone ${ }^{84}$. This disturbing occurrence is observed in many conflicts around the world in clear violation of the rules and principles of international humanitarian law ${ }^{85}$.

\footnotetext{
${ }^{71}$ Sandra Singer, 'Protection of Children in Armed Conflict, Studies in International Humanitarian Law', Dar Al-Mustaqbal Al-Arabi, 2000, 144.

72 Article 17, 'The African Charter on Human and Peoples' Rights', 1986.

73 Article 11, 'The African Charter on the Rights and Welfare of the Child', 1990.

${ }^{74}$ Article 11 (2), African Charter on the Rights and Welfare of the Child, 1990.

75 Article 31, 'American Declaration on Human Rights and Duties of Man', 1948.

${ }^{76}$ Article 12 (4), 'American Convention on Human Rights', 1969.

${ }^{77}$ Wikipedia, 'American Convention on Human Rights', $2018<$ https://en.wikipedia.org/wiki/American_Convention_on_Human_Rights $>$.

78 Article 15 (2), 'The European Convention on Human Rights', 1953.

${ }^{79}$ Víctor Luis and Gutiérrez Castillo, 'The Organization of Islamic Cooperation in Contemporary International Society Sociedad Internacional Contemporánea', Revista Electrónica De Estudios Internacionales, 2014, 4 <www.reei.org>.

${ }^{80}$ Article 41, 'The Arab Charter on Human Rights', 2004.

${ }^{81}$ Article 41 (2), 'The Arab Charter on Human Rights', 2004.

82 Article 12, Covenant on the Rights of the Child in Islam, 2005

${ }^{83}$ ART. 16, Covenant on the Rights of the Child in Islam, 2005.

${ }^{84}$ Vincent (ed.) Bernard, 'War in Cities', International Review of the Red Cross, 98.901 (2016), $65<\mathrm{https}$ ://www.icrc.org/en/internationalreview/war-in-cities>; 'The Evolution of Warfare The Evolution of Warfare', International Review of the Red Cross, 97.900 (2015), 955-964 $<$ https://doi.org/doi:10.1017/S1816383116000497>.

${ }^{85}$ International Committee of the Red Cross ICRC, 'International Humanitarian Law: Its Relevance in Contemporary Conflict', 2008 $<$ https://www.icrc.org/eng/resources/documents/statement/ihl-statement-080508.htm>.
} 
Children may be influenced by violence from the outbreak of hostilities ${ }^{86}$. This suggests that rules must be enforced from the very start of hostilities for the protection of children ${ }^{87}$.

The infuence of war may continue long after hostilities cease, for example through remnants of conflict such as landmines. Other effects include reduced growth and overall development, loss of security, self-confidence and self-esteem and psychological damage ${ }^{88}$. Terror varies from child to child, but has serious infuence on social and emotional development. Children's cognitive development is also troubled during war. Skills such as literacy, numeracy and critical thinking are attained more gently if at all ${ }^{89}$. Article 39 of the Convention on the Rights of the Child necessitates State parties to take essential steps to support the physical and psychological rehabilitation of children and provide for their social reintegration as follows: "State Parties shall take all appropriate measures to promote the physical and psychological recovery and social reintegration of child victims of any form of neglect, exploitation, abuse, torture or any other form of cruel, inhuman or degrading treatment or punishment occurring during armed conflict" $"$.

Graça Machel of Mozambique debated the influence of war on children in 1996 in the General Assembly. He argued that armed conflict has devastating effects on children, wounding bodies and destroying spirits, and presented evidence that millions of children are affected by rape, fear, killing, stress and bereavement ${ }^{91}$. The impact of armed conflict on education has been widely ignored. This hidden crisis strengthens poverty, destroys roads, closes schools and hospitals, undermines economic growth and prevents progress ${ }^{92}$. At the heart of this crisis lie the devastating physical and psychological effects of war on children through direct violence or the destruction of schools ${ }^{93}$. Humanitarian assistance for food, shelter, water and health care has led to the neglect of educational problems. Destruction of schools interrupts education, which is potentially very serious. Failure to provide education leaves generations uneducated, uninformed and unable to contribute to their communities ${ }^{94}$.

\section{Education of Children in War-Torn Countries}

A tragic residue of Middle East conflict is the so-called lost generation; i.e. uneducated children ${ }^{95}$. These children are not only displaced but also denied access to education. They lacked opportunities to develop the skills needed to become contributing members of society. This 'lost generation' is one of the catastrophes of our time. According to a 2018 report by UNICEF, more than 2.7 million Syrian children have been displaced and removed from school ${ }^{96}$. The 2014 Annual Report of the Special Representative of the Secretary-General for Children and Armed Conflict in Iraq and the Syrian Arab Republic noted "the Islamic State in Iraq and the Levant (ISIL) and other groups espousing extremist ideologies used extreme violence that directly or indirectly targeted children. Some ISIL propaganda materials broadcast through web and social media featured sexual exploitation of Yazidi girls, religious indoctrination of children and the use of child soldiers"97. Conflict in Mali has closed at least 115 schools and disadvantaged 700,000 children, including 200,000 who cannot attend school. Even if schools are not closed, children may avoid going to school due to insecurity ${ }^{98}$. The United Nations Children's Fund (UNICEF) in 2017

\footnotetext{
${ }^{86}$ Joshua Yuvaraj, 'When Does a Child "Participate Actively in Hostilities" under the Rome Statute? Protecting Children from Use in Hostilities after Lubanga', Utrecht Journal, $2016<$ https://doi.org/http://doi.org/10.5334/ujiel.321>.

${ }^{87}$ UNSC, 'Children's Rights Violations during Armed Conflicts on Rise despite National Action Plans to End Abuse, Security Council Told in Day-Long Debate', $2016<\mathrm{https} / /$ www.un.org/press/en/2016/sc12470.doc.htm>.

${ }^{88}$ ICRC, 'Children in War', Icrc, 2009, 4.

${ }^{89}$ Dr. Theresa S. Betancourt, 'Interventions for Children Affected by War: An Ecological Perspective on Psychosocial Support and Mental Health Care', Harv Rev Psychiatry, 2013, p. $1<$ https://doi.org/10.1097/HRP.0b013e318283bf8f $>$.

${ }^{90}$ Unicef, 'FACT SHEET : A Summary of the Rights under the Convention on the Rights of the Child', Advance Humanity, 1 (2011), 4 $<$ https://www.unicef.org/crc/files/Rights_overview.pdf $>$.

${ }^{91}$ UNESCO, 'Paths to Hope UNESCO’s Programme for the Education of Children in Need', 2003, 17-19.

${ }_{92}$ Pieter Serneels and Marijke Verpoorten, 'The Impact of Armed Conflict on Economic Performance', Journal of Conflict Resolution, 59.9 (2015), $22<$ https://doi.org/10.1177/0022002713515409>.

${ }^{93}$ Fuaad Mohammed Freh, 'Psychological Effects of War and Violence on Children', Journal of Psychological Abnormalities, 2015, 1 $<$ https://www.omicsonline.org/open-access/psychological-effects-of-war-and-violence-on-children-jpab-S1-e001.php?aid=68333>.

${ }^{94}$ OECD, 'Keeping Children Safe in Education', 2015, $9<\mathrm{https} / /$ doi.org/10.1787/9789264106314-en>.

${ }^{95}$ M. J. Kehily, 'Understanding Childhood : An Introduction to Some Key Themes and Issues', An Introduction to Childhood Studies, 2004, $13<\mathrm{https}$ ://doi.org/10.1177/009430610603500214>.

${ }^{96}$ UNICEF, 'UNICEF RESPONSE TO THE SYRIA CRISIS January 2014’, 2014, 4-6.

${ }^{97}$ UN General Assembly, 'Annual Report of the Special Representative of the Secretary-General for Children and Armed Conflict, Leila Zerrougui', 2014, p. 3.

98 United Nations International Children's Emergency Fund, 'UNICEF Annual Report 2013', 2014, 1 $<\mathrm{http} / / /$ www.unicef.org/publications/files/UNICEF_Annual_Report_2013_web_26_June_2014.pdf>; United Nations, 'Armed Conflict in Africa', $2018<$ http://www.un.org/ar/sections/issues-depth/africa/index.html $>$.
} 
stated that after the sixth anniversary of South Sudan's independence, children continue to bear the brunt of the conflict and collapsing crucial services, noting that "Millions of children in South Sudan are suffering unthinkable hardships and setbacks in their education, nutrition, health and other rights" $" 99$.

High education levels reduce the incidence of civil war, while failure to enroll adolescent refugees in schools hinders reconstruction efforts and fuels instability ${ }^{100}$. UNESCO reported in 2014 that countries with at least 30 percent of children in secondary education were able to later double this ratio and halve the risk of further conflict. When children are forced to flee in search of safety, education is the victim ${ }^{101}$. A 2012 Human Rights Watch report revealed that the risk of forced recruitment and abduction in Somalia, where parties to the conflict abduct children for enforced military service, caused children to flee and thus miss out on education. It was reported that the school dropout rate was 50 percent following an attack in a certain place in 2010. Al-Shabaab abducts girls for general service and as wives for fighters. Families trying to flee or prevent their children from being abducted face severe consequences. In many areas, children do not have access to schools. School participation rates of girls are lower than those of boys because their risk of attack and abduction is higher ${ }^{102}$.

Recent revolutions have gravely affected educational facilities in the Arab world. Countries involved in the Arab Spring have experienced failing educational services, high drop-out rates and displacement to refugee camps in neighboring countries, where access to educational services is limited ${ }^{103}$. A UNICEF report of September 3, 2015 stated that internal conflicts prevented 13.4 million children, a number equivalent to $40 \%$ of the total number of school-age children, from receiving schooling in Syria, Iraq, Yemen, Libya and Southern Sudan, 3.1 million children dropped out in Sudan, 3 million in Iraq, 2.9 children in Yemen, 2.7 million in Syria and the Syrian refugee areas in Jordan, Lebanon, Turkey and Egypt, and 2 million in Libya. In Libya, enrollment levels in educational institutions declined by $50 \%$ in 2015 as a result of civil conflict ${ }^{104}$.

Government responses have further complicated the situation of refugee and displaced children ${ }^{105}$, based on a report by Human Rights in 2015 on police abuses against Afghans in Pakistan. After an attack by the Taliban in Pakistan in December 2014 which killed 132 secondary school children in Peshawar led to increasing violence against Afghans living in Pakistan, authorities restricted access to social services of Afghan refugees ${ }^{106}$. In Nigeria, children have been killed, abducted, and internally displaced, "while others have sought refuge in neighboring countries". The Government's response to the Boko Haram group led to the abduction of more than 200 girls from a secondary school in Shibok, Borno State in April 2014. North-eastern Nigeria in 2014 was one of the world's most murderous places for children. ${ }^{107}$. A 2015 statement by the United Nations Children's Fund (UNICEF) expected that Middle East and North Africa conflicts have forced 13 million children out of school ${ }^{108}$. A UNHCR report at that time indicated that only half of the estimated 3.5 million primary school-aged children in those regions had access to education. Up to $40 \%$ of eligible children in Syria were not educated ${ }^{109}$. Only $13 \%$ of

\footnotetext{
99 UNICEF, 'Six Years after Independence: South Sudan's Children Wait for Peace and Prosperity', 2017 $<$ https://www.unicef.org/media/media_96614.html >.

${ }^{100}$ Hania Kamel, 'Early Childhood Care and Education in Emergency Situations', UNESCO, 2007, 11.

${ }^{101}$ Taormina Progress Report, 'Investing in Education for Mutual Prosperity, Peace and Development', 2017, 15.

${ }^{102}$ Human Rights Watch, 'No Place for Children Child Recruitment, Forced Marriage, and Attacks on Schools in Somalia', 2012, p. 1 $<$ https://www.hrw.org/report/2012/02/20/no-place-children/child-recruitment-forced-marriage-and-attacks-schools-somalia $>$; US Department of State, 'Somalia 2015 Human Rights Report Executive Summary', 2015, $36<$ https://www.state.gov/documents/organization/252939.pdf>

${ }^{103}$ Eid Mohamed, Slimane Aboulkacem, and Hannah R. Gerber, Education and the Arab Spring: Resistance, Reform, and Democracy, Education and the Arab Spring: Resistance, Reform, and Democracy, 2016<https://doi.org/10.1007/978-94-6300-471-8>; Felix Korbieh, 'The Arab Spring : Implications for Africa', 2014, 21.

104 Time, '13 Million Middle Eastern Children Are Unable to Attend School', $2015<$ http://time.com/4021101/middle-east-children-educationunicef-report/>; Unicef, 'Conflict Drives 13 Million Children out of School in the Middle East and North Africa', 2015, 1 $<$ https://www.unicef.org/infobycountry/media_83072.html>.

${ }^{105}$ Unher, 'Refugee Children: Guidelines on Protection and Care', 1994, 7.

106 The experess Tribune, 'Human Rights Watch Urges Pakistan to End Police "harassment" of Afghan Refugees', 2015 $<$ https://tribune.com.pk/story/993881/human-rights-watch-urges-pakistan-to-end-police-harassment-of-afghan-refugees/>; Human Rights Watch, 'What Are You Doing Here?' Police Abuses Against Afghans in Pakistan', 2017, p. $1<$ https://www.hrw.org/report/2015/11/18/whatare-you-doing-here/police-abuses-against-afghans-pakistan>.

107 ACAPS Secondary Data Review, 'Northeast Nigeria Conflict', 2015, 12; Ebenezer Durojaye Aisosa Jennifer IsokpanI, 'Impact of the Boko Haram Insurgency on the Child's Right to Education in Nigeria', Scielo, 2016, $1<$ https://doi.org/http://dx.doi.org/10.17159/17273781/2016/v19n0a1299>.

${ }^{108}$ UNICEF, 'Middle East and Northern Africa', $2015<\mathrm{https}: / /$ www.unicef.org/media/media_pr_mena.html $>$.

${ }^{109}$ UNHCR, 'Missing Out Refugee Education in Crisis 2', 2016, $11<\mathrm{http}$ ://uis.unesco.org/sites/default/files/documents/missing-out-refugeeeducation-in-crisis_unher_2016-en.pdf>.
} 
refugee children of secondary school age in Turkey receive education ${ }^{110}$, with even lower figures in Cameroon $(6 \%)$, Pakistan (5\%) and Lebanon (5\%). In 2008, only $69 \%$ of refugee children of elementary school age attended school in UNHCR camps ${ }^{111}$.

According to a UNESCO declaration of 1953, "education is best carried out through the mother tongue of a pupil"112. Article 75(1) of the 1977 Additional Protocol I offers that education shall be accessible "without distinction based upon race, color, sex, language, religion, belief, opinion, origin, wealth, status or other criteria"113. However, Syrian children in occupied Golan are deprived of the cultural rights guaranteed by international conventions, since Israeli culture, language and curricula are imposed on them, which amounts to an attempt to distort the social and political identity of these children and isolate them from any intellectual or cultural ties to their homeland ${ }^{114}$. International laws indicate an immediate cessation of violence against children globally is required. All children should be able to learn in a non-violent environment, and schools must be both safe and appropriate for children ${ }^{115}$.

Article 28 of the Convention on the Rights of the Child provides for the education rights of children, noting that States should "encourage the development of different forms of secondary education, including general and vocational education, make them available and accessible to every child, and take appropriate measures such as the introduction of free education and offering financial assistance in case of need"116. This highlights the right of the child to education and guarantees that such education is free and available and in conformity with the human dignity of the child. Armed conflict interrupts the lives of children, and can even lead to misery, poverty, sexual abuse or the buying and selling of children like merchandise. Grave violations of the rights of children occur due to not only direct effects but also to interruptions to basic elements such as infrastructure, health, education and food. All the above effects should be considered important measures in this field.

Violations of education rights frequently occur in times of emergency and long-term crisis ${ }^{117}$. Although education is vital for economic growth, peace and stability, a systematic problem exists in the education practices of the Middle East and North Africa. Education is of low quality, with even basic skills not successfully transmitted. Since 2005, armed groups have utilized schools and universities for military aims in 26 countries, and between 2009 and 2013 there were systematic attacks against educational centers in 30 countries. So long as crises are ongoing, those impacted may increase. A 2015 UNICEF data analysis shows that 55 countries are in crisis, which affects 476 million children aged 3 to 15 years. ${ }^{118}$. Deprivation of education has short- and long-term negative consequences for children and their communities.

\section{Attacks on Educational Facilities, Students, Teachers and Education Staff in Armed Conflict}

Organized and deliberate attacks on educational facilities are a significant problem. In the Swat district of Pakistan, for instance, 200 schools were destroyed by the end of 2008, of which 95 per cent were female. It is estimated that approximately 50,000 students have been denied education due to these attacks ${ }^{119}$. The Ministry of Education of Gaza, in the Occupied Palestinian Territory, approximates that Israeli military attacks in 2008 and 2009 "killed 350 children, wounded 1,815, and destroyed 280 schools". Over $70 \%$ of girls' schools have been closed by the Taliban. In Iraq, sectarian violence has included the targeting of schools. In Thailand, attacks on schools and

\footnotetext{
110 JASON BEAUBIEN, '5 Surprising Facts About The Refugee Crisis', 2017 $<$ https://www.npr.org/sections/goatsandsoda/2017/06/20/533634405/five-surprising-facts-about-the-refugee-crisis>; Human Rights Watch, 'The Lost Years Secondary Education for Children in Emergencies', $2017<$ https://www.hrw.org/world-report/2017/country-chapters/global$0>$.

111 Annual Report, 'Dafi 2016 ANNUAL REPORT', Unhcr, 2016, 11.

112 UNESCO Declaration of 1953, (p.6).

113 Article 75(1), 'Additional Protocol I', 1977.

${ }^{114}$ Foreign affairs of the syrian arab Republic, 'Report of the Special Committee to Investigate Israeli Practices Affecting the Human Rights of the Palestinian People and Other Arabs of the Occupied Territories', 1997 <https://uniteapps.un.org/_ 852560d3006f9c53.nsf/5ba47a5c6cef541b802563e000493b8c/045cedb60df4fb35052564eb003133ba>.

115 unicef, 'Ending Violence Against Children: Six Strategies for Action', 2014, 18.

116 Convention on the Rights of the Child, Article 28, $1990<$ https://www.ohchr.org/en/professionalinterest/pages/crc.aspx>.

117 UNICEF, 'Children in Humanitarian Crise: What Business Can Do', 2016, $<$ https://www.unicef.org/corporate_partners/files/CHILDREN_IN_HUMANITARIAN_CRISES.pdf>.

118 Susan Nicolai, Sébastien Hine, and Joseph Wales, 'Education in Emergencies and Protracted Crises: Toward a Strengthened Response', London, ODI, 2015, 9 <https://doi.org/https://www.odi.org/sites/odi.org.uk/files/odi-assets/publications-opinion-files/9714.pdf>; Unicef, Humanitarian Action for Children: Building Resilience, New York: UNICEF, $<$ http://scholar.google.com/scholar?hl=en\&btnG=Search\&q=intitle:Humanitarian+Action+for+Children+building+resilience\#0 $>$.

119 Refworld, 'Information on Discrimination against the Female Child', 2011, 2.
} 
killings of teachers have led to the closure of schools ${ }^{120}$.

Attacks on educational facilities are often not the focus of international attention. Targeting of university buildings has increased significantly over the past ten years ${ }^{121}$. The Global Alliance for the Protection of Educational Institutions from Attacks reported an increase in armed attacks targeting educational institutions, particularly in Afghanistan, Syria, Yemen, Iraq, Sudan, Colombia, Somalia, Nepal, the Palestinian Autonomous Territories, Thailand and Zimbabwe ${ }^{122}$. According to the report, educational institutions were exposed to more than 12,700 attacks between 2013 to $2017^{123}$.

The Special Representative of the Secretary-General Assembly for Children and Armed Conflict of the United Nations advised in 2006 that schools "have become increasingly the primary target of attacks by armed parties". Detonations of IEDs in universities and education offices have become more common among militant groups ${ }^{124}$. In Afghanistan, a Human Rights Watch recognized 204 reported attacks on teachers, students and schools between January 2005 and June 2006. Amnesty International stated that in that period, attacks on teachers, students and other education personnel enhanced, and that " 75 students, teachers and other school staff were killed in attacks. In 2005, there were 11 explosions, 50 cases of burning and one rocket attack." ${ }^{125}$.

According to the FECODE, 310 teachers and 11 students were murdered between 2000 and 2008. Further reports indicate that between 2009 and 2012, 140 teachers were killed, more than 1,000 school teachers received death threats and 965 students dropped out of education institutions after being threatened ${ }^{126}$. In Iraq, according to statistics from the Iraqi Ministry of Education, 300 teachers were killed and 1158 were injured between November and December in 2006, while many schools were closed due to violence and threats. Between 1996 and 2006 in Nepal, 145 teachers and 344 students were murdered and 79 schools destroyed ${ }^{127}$. In Kenya, gunmen murdered at least 142 students and injured 79 others on April 2, 2015, during an attack on Garissa University ${ }^{128}$. UNICEF reported that the Sudan Liberation Movement / Army (SLA) abducted 108 children on 26 May 2006 and that a school and teacher training institute was attacked in May $2006^{129}$. There are no overall and audited figures on education-related abuses in northern or southern Sudan.

Armed conflict affecting the lives of teachers and students is unpleasant and contrary to morality, since it leads students and educational staff to remain at home for fear of attacks ${ }^{130}$. The consequences of these actions cause fear and tension and impede educational endeavors, enthusiasm and attendance. The impact of violent attacks on education is devastating ${ }^{131}$.

\section{Teacher Shortages in Armed Conflict Situations}

Teacher shortages are a major challenge to education in times of armed conflict. The UN has estimated that "69 million new teachers will be required globally to achieve primary and secondary education goals by 2030 "132.

\footnotetext{
${ }^{120}$ Naushad Khan, 'Critical Review of Past Literature of Militancy Impact on Educational Institutions in the World Critical Review of Past Literature of Militancy Impact on Educational Institutions in the World', 2018, 8.

121 Brendan O'Malley, 'Education under Attack', Development, 27.April (2007), 3.

122 IDMA Internal displacement monitoring centre, 'Global Overview 2011 People Internally Displaced by Conflict and Violence’, 2012, $15 \_19$.

123 Alghadpress, 'Educational Institutions in the World Have Suffered More than 12.7 Thousand Attacks', 2018

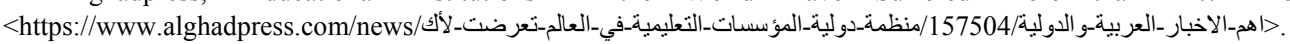

${ }^{124}$ A/61/275, 'Report of the Special Representative to the Secretary General for Children and Armed Confl Ict', 2016.

125 Brendan O'Malley, 'GLOBAL: Education under Attack', University Word News, 2008 $<$ http://www.universityworldnews.com/article.php?story=20081106153948573>.

${ }^{126}$ GCPEA, 'Attacks on Schools (COLOMBIA)', 2014, 2.

127 Raj Kumar Dhungana, 'School Violence in Nepal', Ministry of Education, 2014, 5.

${ }^{128}$ Christopher Wakube and others, 'Inside Kenya's War on Terror: Breaking the Cycle of Violence in Garissa', 44.1043843 (2015), 1 $<$ https://static1.squarespace.com/static/58921b4b6b8f5bd75e20af7e/t/597f105886e6c03d8024f59b/1501499494866/breaking-the-cycle-ofviolence-in-garissa-v2.pdf $>$.

129 Security Council United Nations, 'Report of the Secretary-General on Children and Armed Conflict in the Sudan', 2006, 7 $<$ https://doi.org/S/2010/579>.

130 parliament of Australia, 'The School Environment - Factors Affecting Teachers' Morale, Performance and Status', 2018 $<$ https://www.aph.gov.au/Parliamentary_Business/Committees/Senate/Education_Employment_and_Workplace_Relations/Completed_inqui ries/1996-99/teachers/report/c06>.

${ }^{131}$ Patricia Justino, 'How Does Violent Conflict Impact on Individual Educational Outcomes? The Evidence So Far', Education for All Global Monitoring Report, 2010, 3.

132 UN News, Nearly 69 Million New Teachers Needed to Achieve Global Education Goals, UNESCO Reports, 2016 $<$ https://news.un.org/en/story/2016/10/541902-nearly-69-million-new-teachers-needed-achieve-global-education-goals-unesco>.
} 
Teachers, student and schools today are on the front line in armed conflict, with teachers and students seen by armed groups as legitimate targets ${ }^{133}$. According to United Nations reports, children fear going to school, teachers fear teaching and parents fear sending children to school. Attacks on teachers have impacted both education systems as a whole and education rights ${ }^{134}$.

Since 2017, in Pakistan and Afghanistan, teachers, professors, academicians and other education staff have been raped, imprisoned, beaten, tortured, or shot by rebels, armies and repressive regimes, in or on their way to school ${ }^{135}$. UNICEF in 2017 reported that over 70 per cent of Yemen's children are denied education because of the teacher shortage. Since October 2016, 73\% of teachers in Yemen have received no wages. Up to $78 \%$ of schools there have closed or have too few teachers, with 13,000 schools and 5,000,000 children affected by this situation ${ }^{136}$. Teachers sometimes relocate to safer areas that are able to meet their basic needs for safety and remuneration. For example, in Syria, at least 52,500 teachers have left jobs in volatile areas for neighboring countries or alternative in-country locations ${ }^{137}$.

\section{Gender Discrimination in Education in Armed Conflict Situations}

Another challenge to education, mostly in times of armed conflict, is gender discrimination. Being female may lead to not receiving education, especially during armed conflict ${ }^{138}$. More than $130,000,000$ young women worldwide today have not received basic education. ${ }^{139}$. In Afghanistan, Taliban forces targeted girls' education after 2001. By 2004, only 5\% of girls were in secondary education. In 2005, attacks on schools increased. Taliban forces distributed "night messages" threatening schools, ordering girls to drop out of school at puberty, killing students and teachers, kidnapping children, throwing acid at the faces of teenage girls and targeting girls' ${ }^{140}$ schools with rockets, fire and explosive charges. Desperate poverty forces about a quarter of Afghan children to work to help their families survive, and many girls weave, embroider, beg, or pick garbage rather than study ${ }^{141}$. Thus, violence, poverty and discrimination combine to reduce the number of girls in schools.

According to a 2013 UNESCO report, about 20,000,000 girls are living in conflict-affected countries. Girls account for $30 \%$ of refugees in secondary education and are vulnerable to sexual violence and exploitation in conflict. The international community is working to protect education rights, particularly of girls, by organizing a symposium jointly hosted by the UNESCO International Institute for Education Planning (IIEP), the Inter-Agency Network for Education in Emergencies (INEE) and the Working Group on Education of the Vulnerable in order to contribute to peacekeeping and conflict prevention through conflict prevention strategies ${ }^{142}$.

A 2017 Human Rights Watch's report lists a range of obstacles facing girls in education including discrimination by government officials and community members, early marriage, attacks on educational centers, military use of schools, kidnappings, acid attacks, sexual harassment, poverty, forced labor, lack of schools, poor infrastructure, lack of facilities in schools, low quality of education, lack of vocational training, lack of teachers, lack of female teachers, administrative barriers to transferring between schools and lack of cultural acceptance of the need for education for girls ${ }^{143}$.

\footnotetext{
${ }^{133}$ Alan Smith, 'Contemporary Challenges for Education in Conflict Affected Countries', Journal of International and Comparative Education, 3.1 (2014), 114

${ }^{134}$ D. Adams, 'Defining Quality in Education', Improving Educational Quality Project, Biennial R.1 (1993), 8_10.

${ }^{135}$ Human Rights Watch, 'Attacks on Students, Teachers, and Schools in Pakistan', $2017<$ https://www.hrw.org/report/2017/03/27/dreamsturned-nightmares/attacks-students-teachers-and-schools-pakistan>.

${ }^{136}$ United Nations, 'The United Nations Education Children's Fund (UNICEF) 2017', 2017, 3-5; unicef yemen, 'Report of Unicef Yemen in Education', $2018<\mathrm{https}: / /$ www.unicef.org/yemen/>.

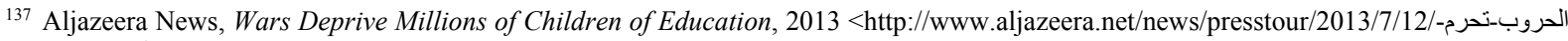
>ملايين-الأطفال-من-التعليم>

138 Adams.

139 Ohchr, 'Human Rights of Women and Gender Equality', 2018

$<$ https://www.ohchr.org/ar/Issues/Women/WRGS/Pages/WRGSIndex.aspx>.

${ }^{140}$ for example, yousafzai, malala the girl who stood up for education and was shot and his rights violated by the taliban.

${ }^{141}$ BBC NEWS, 'Taliban Territory: Life in Afghanistan under the Militants', 2017, p. $1<$ https://www.bbc.com/news/world-asia-40171379>; Human Rights Watch, 'Afghanistan: Girls Struggle for an Education', 2017, p. $1<$ https://www.hrw.org/news/2017/10/17/afghanistan-girlsstruggle-education>.

${ }^{142}$ UNESCO, 'Careful Education of Conflict Situations: Objectives and Means of Provision', $2013<\mathrm{http}$ //www.unesco.org/new/ar/mediaservices/single-view/news/conflict_sensitive_education_why_and_how/>.

143 Human Rights Watch, 'The Report of Human Rights Watch in 2017 Education in Afghanistan', 2017 $<$ https://www.hrw.org/gbz/report/2017/10/17/310154>.
} 


\section{The Cost of Education in Armed Conflict Situations}

A further significant challenge to education associated with armed conflict is cost. International humanitarian law safeguards under the UNCRC do not essentially promise a sustainable model that guarantees a child's right to access to education, and a major problem is $\cos ^{144}$. Up to $\$ 8$ billion per year, which includes school fees, teacher retraining programs, learning materials and reconstruction of schools is required to offer educational support to the 65 million children aged 3 to 15 who are affected by protracted conflicts globally. New analysis from Save the Children, the British Teachers' Center and American research institutes highlights the high economic cost of the 2.8 million Syrian children out of school, estimating the cost of replacing or repairing schools and equipment alone at $\$ 3$ billion. The long-term impact of lost education has been estimated at 5.4\% of GDP, or about $\$ 2.18$ billion $^{145}$. However, less than 2 percent of humanitarian aid goes towards education ${ }^{146}$.

Since 2011, the Global Education Partnership (GPE) has helped rehabilitate or create 53,000 classrooms. The GPE estimates that with an additional $\$ 3.1$ billion it could help create or repair 23,800 classrooms and train or retrain 1.7 million teachers ${ }^{147}$. Most international funding for education comes from development support. In 2012, humanitarian funding for education in conflict areas was $\$ 105,000,000$. Although many Middle Eastern countries have ratified the UNCRC, the scale of the humanitarian education response is limited. It is crucial to identify measures to improve access to education during protected conflict ${ }^{148}$. For example, the government of Jordan has waived tuition fees for Syrian refugees in public schools ${ }^{149}$, and in Lebanon, tuition fees are covered by the Ministry of Education and Higher Education, UNHCR and UNICEF ${ }^{150}$. UNHCR and UNICEF cover fees for uniforms, books, bags and stationery for students in Syria, Lebanon and Jordan. Nevertheless, in Lebanon many children remain out of school ${ }^{151}$.

It must be approved that the cost of providing education is high. Nonetheless, the cost of not doing so is far higher. Continued education in times of armed conflict is a serious long-term investment in children which guarantees that a state will not be short of human capital in future.

\section{Protecting Students and Education Staff}

Thirty-seven countries joined the Universal Declaration of Safe Schools on May 29, 2015. According to the International Declaration on Safe Schools, countries committed to protecting schools and universities have experienced widespread clashes and raids. In the wake of wars and attacks, schools and universities, students and their staff are seriously injured ${ }^{152}$. Many schools and universities have been converted to military bases. By joining this Declaration, countries agree on strategies to protect schools and universities during armed conflicts ${ }^{153}$. According to The Safe Schools Declaration, "all armed forces should refrain from targeting educational centers or turning them into military bases.".

More than 72 million children are deprived of basic education around the world; half of those are in countries afflicted armed conflicts ${ }^{154}$. Conflict is not a sufficient reason to restrict educational opportunities, since involved parties in armed conflict have a duty to provide education in their areas. Humanitarian law dictates that education should continue in emergency situations ${ }^{155}$. For example, the Fourth Geneva Convention obliges occupation

\footnotetext{
${ }^{144}$ Article 28, 29, 38 and 39 of The UNCRC Convention.

145 Sasapost, 'Cost of War', 2015 <https://www.sasapost.com/cost-of-war/>.

146 global partnership for Ducation, 'New Fund Launches to Address Global Education Crisis', 2016 $<$ https://www.globalpartnership.org/news-and-media/news/new-fund-launches-address-global-education-crisis $>$.

${ }^{147}$ Globalcitizen, '10 Barriers to Education Around the World', $2018<\mathrm{https} / /$ www.globalcitizen.org/en/content/10-barriers-to-educationaround-the-world-2/>.

${ }^{148}$ Unicef, 'Middle East and North Africa', $2018<\mathrm{https}$ :/www.unicef.org/appeals/mena.html>.

149 Ahmad Al-Hawamdeh and Hana A. El-Ghali, 'The Regional Conference on Higher Education in Crisis Situations : " Higher Education in Crisis Situations : Synergizing Policies and Promising Practices to Enhance Access, Equity and Quality in the Arab Region "', Unesco Regional Bureau for Education in the Arab States - Beirut, 2017, 12.

${ }^{150}$ nisrine makkouk and suha tuttunji Maha shuayb, 'Widening a Ccess to Quality e Ducation for Syrian Refugees: The Role of Private and Ngo Sectors in Lebanon', 2014, 48.

${ }^{151}$ UNHCR, 'Missing Out Refugee Education in Crisis 2', p. 13.

152 the Norwegian Ministry of Foreign Affairs, 'The Oslo Conference on Safe Schools Protecting Education from Attack', $2015,27$.

153 Global Coalition to Protect and Attack, 'Protecting Schools and Universities from Military Use', 2018 $<$ http://www.protectingeducation.org/restricting-military-use-and-occupation $>$.

${ }^{154}$ Save The Children, 'The Future Is Now: Education for Children in Countries Affected by Conflict', 2010, 8.

${ }^{155}$ Françoise J Hampson, 'Legal Protection Afforded to Children under International Humanitarian Law', University of Essex, UK, 1996 $<$ https://www1.essex.ac.uk/armedcon/story_id/000578.html>.
} 
authorities to facilitate "appropriate work for educational institutions in the occupied territories". The Convention itself emphasizes "parties to a conflict must ensure that the education of these children is facilitated under any circumstances" $" 156$.

\section{Protecting Educational Facilities}

When armed groups utilize schools and universities as military bases, barracks, weapons caches or prisons, not only are students enforced to depart, but these places become military targets. Armed conflict destroys educational facilities by using them as military areas ${ }^{157}$, which is banned by Article 8 of the Rome Statute of the international criminal court as follows: "[It is prohibited to intentionally direct attacks against buildings dedicated to education ... provided they are not military objectives" $" 158$. In 2015, at least 8,850 schools and other educational facilities were destroyed in Syria, Iraq, Yemen, Libya and Sudan. A report issued by the Syrian Center for Human Rights in early 2015 confirmed the destruction of at least 3,994 schools in Syria, including about 450 in the governorates of Homs, Damascus and Aleppo. Some 1,500 schools were converted to displaced persons' residences, 150 schools to field hospitals and several more to detention centers and security bases for the regime or the armed opposition $^{159}$.

According to a Human Rights Watch report of 2017, 40 involved States did not provide even basic protection for schools at risk of violent incursion. This lack of protection, as well as the commandeering of schools for military purposes, threaten the safety of pupils and teachers and influences the right of pupils to education ${ }^{160}$. The 2018 report of the Global Coalition to Protect Education from Attack (GCPEA) stated that "hundreds of schools and higher education facilities have been damaged or destroyed" in the Democratic Republic of the Congo (DRC), Egypt, Palestine, Nigeria, the Philippines, South Sudan, Syria, Turkey and Yemen. Attacks on educational facilities constitute threats to the security of student and educational staff and destruction or disruption educational facilities that result to human rights violations ${ }^{161}$. Article 3 of the Convention on the Rights of the Child that reports that "State Parties shall ensure that the institutions, services and facilities responsible for the care or protection of children shall conform with the standards established by competent authorities, particularly in the areas of safety, health, number and suitability of staff and competent supervision"162. It is essential that the State ensure these educational facilities are available and prevent their closure, because "the failure of the State to sustain available schooling constitutes an apparent violation of the right to education"163.

International humanitarian law prohibits indiscriminate attacks on educational facilities and establishes responsibility for the preservation of civilian property in situations of international ${ }^{164}$ and non-international ${ }^{165}$ armed conflict. The ICRC necessitates all parties in armed conflict to respect children and teachers, as well as educational facilities, and to take all probable measures to limit the utilization of such civilian buildings for goals that could result in loss of protection under humanitarian law ${ }^{166}$.

\section{Rethinking Education Models}

Disruption makes it difficult for children to resume their progress through traditional curricula when schools reopen. This situation triggers despair and sometimes anger, and causes some families to risk their lives crossing borders and seas in search of educational opportunities for their children, often fueling tensions in host communities. Students graduate with different grades than they otherwise would have, and may fail because of poor performance according to a lack of understanding or incomplete assignments. Dropping out of education,

\footnotetext{
156 Articles 50 (1) and 24 (1), The Fourth Geneva Convention, 1949.

157 Ashley Ferrelli, 'Military Use of Educational Facilities during Armed Conflict: An Evaluation of the Guidelines for Protecting Schools and Universities from Military Use during Armed Conflict as an Effective Solution', Ga. J. Int'l \& Comp. L., 44.2 (2016), 343.

158 Article 8 (iv), Rome Statute of the International Criminal Court, 1998.

159 Alsouria.net, 'Syria 2015', $2105<$ https://www.alsouria.net/frontpage?page=1853>; Human Rights Watch, 'The Events of 2016 in Syria', 2016.

160 Al-sharq, 'International Warning of Schools and Universities Being Violated during Armed Conflict', $2017<$ https://www.alsharq.com/news/details/477931>.

161 Catherine Benson Wahlén, 'Report Finds Increasing Attacks on Education', IISD, $2018<$ http://sdg.iisd.org/news/report-finds-increasingattacks-on-education/>.

162 Article 3, 'Convention on the Rights of the Child', 1989.

163 UNHCR, 'Progress Report of the Special Rapporteur on the Right to Education, Para.32', 1950.

164 Article 2(b)(ii), (ix), (xiii) and (xxiv), Rome statute of the international criminal court, 1998.

165 Article 2(e)(ii), (iii), (iv) and (xii), Rome Statute of the International Criminal Court, 1998.

166 R.K. DIXIT, 'Special Protection Of Children During Armed Conflicts Under The Geneva Conventions Regime', 2018 $<$ http://www.worldlii.org/int/journals/ISILYBIHRL/2001/2.html $>$.
} 
whether due to destruction of educational facilities or to other reasons, can endanger a child's physical and mental development and have emotional, psychological and educational outcomes which can lead to academic delays and loss of academic motivation. This makes rehabilitation difficult, and in some cases, even impossible ${ }^{167}$. However, all students need to receive adequate basic education, even if this means spending extra years at school. Thus, traditional education models need to be rethought ${ }^{168}$.

To avoid loss of motivation during intense fighting, when schools are bombed or otherwise destroyed and students cannot attend school ${ }^{169}$, schools can continue to provide education through distance learning or a combination of classroom and distance learning. Distance education generally involves the utilization of telephone, email and Skype to reach students ${ }^{170}$. Students and educators alike acknowledge that the feature of teaching and education through classroom learning is better. Declines in quality of education and changes in delivery methods may affect both educational systems and students for many years, even after normal services are resumed ${ }^{171}$. However, some level of continuing education during armed conflict is essential, and imperfect solutions are better than no solutions.

\section{International Human Rights Law}

International human rights law, defends the lives and welfare of students and education staff in all conditions. The Universal Declaration of Human Rights of the United Nations General Assembly of 1948 notes in Article 1 that "All human beings are born free and equal in dignity and rights" and in Article 3 that "Everyone has the right to life, liberty and security of person". International humanitarian law also confirms the right not to be deprived of life arbitrarily. Article 3, common to the four Geneva Conventions, bans "violence to life and person, and in particular murder, mutilation, cruel treatment and torture" against persons not taking an active part in armed conflict. The International Covenant on Civil and Political Rights of 1966 notes in Article 6 that: "Every human being has the inherent right to life. This right shall be protected by law. No one shall be arbitrarily deprived of his life".

The provisions of international human rights law also ensure the right to liberty and security of students and education staff. The International Covenant on Civil and Political Rights (ICCPR) notes that "Everyone has the right to liberty and security of person. No one shall be subjected to arbitrary arrest or detention"172. Article 7(3) of the American convention on human rights (IACHR) reports "No one shall be subject to arbitrary arrest or imprisonment"173. Denial or abuse of the right of liberty and security of students and education staff troubles their capacity to develop their personalities and undermines proper participation in social, political and economic life. At the level of society, such denial is harmful to democracy and social progress and thus to global peace and human security ${ }^{174}$. The freedom of students and education staff in thought, conscience and religion must be conserved, as reported by Article 26(3) of the Human Rights Universal Declaration ${ }^{175}$. Article 18 (1) of the International Covenant on Civil and Political Rights notes that "Everyone shall have the right to freedom of thought, conscience and religion. This right shall include freedom to have or to adopt a religion or belief of his choice, and freedom, either individually or in community with others and in public or private, to manifest his religion or belief in worship, observance, practice and teaching"176.

Other violations against students and education staff in armed conflict which are forbidden include torture and discrimination. Article 7 of the ICCPR forbids torture of students and education staff in the following terms: "No one shall be subjected to torture or to cruel, inhuman or degrading treatment or punishment"177. National and international laws approve that torture and ill-treatment are actions that are far from the satisfactory standard of

\footnotetext{
${ }^{167}$ Human Rights Watch, The Education Deficit: Failures to Protect and Fulfill the Right to Education in Global Development Agendas, 2016 $<$ https://www.hrw.org/sites/default/files/report_pdf/educationdeficit0616web_0.pdf>.

168 Antonio Fernández-Cano Luisa Cervantes-Duarte, 'Impact of Armed Conflicts on Education and Educational Agents: A Multivocal Review', Scielo, $2016<$ https://doi.org/dx.doi.org/10.15359/ree.20-3.12>.

169 Alina Balta, 'PROTECTION OF SCHOOLS DURING ARMED CONFLICT', International Crimesdatabase, $2015,2$.

${ }^{170}$ Human Rights Watch, Human Rights Watch Interview with Viktoria Vasilievna and with Olga Vladimirovna, 2015.

171 Sara Rimm-Kaufman, 'Improving Students' Relationships with Teachers to Provide Essential Supports for Learning' $<$ http://www.apa.org/education/k12/relationships.aspx $>$.

172 Article 9, International Covenant on Civil and Political Rights (ICCPR), 1966.

173 Article 7(3), American Convention on Human Rights, 1969.

${ }^{174}$ Richard Pierre Claude; Sabina Alkire and Séverine Deneulin, 'Introducing the Human Development and Capability Approach', 2009 $<$ https://prd-idrc.azureedge.net/sites/default/files/openebooks/470-3/index.html>.

175 Article 26(3), 'Human Rights Universal Declaration', 1948.

176 Article 18 (1), 'International Covenant on Civil and Political Rights(ICCPR)', 1966.

177 Article 7, International Covenant on Civil and Political Rights (ICCPR), 1966.
} 
ethics and common practice in the community ${ }^{178}$. International human rights law also forbids discrimination on grounds of race, color, sex, language, religion, political or other opinion, national or social origin, property, place of birth or status, or for any other reason. It should be stated that article 2(1) of the Universal Declaration forbids "discrimination of any kind" which may mean that no difference can be legally accepted in any way. Furthermore, the Convention sets out in some detail the requirement of State parties to eradicate racial discrimination against students and education staff. ${ }^{179}$ International Human Rights Law specifies that all children have the right to freedom, primary education, non-discrimination and appropriate training and supportive measures such as free education and financial assistance if required. States are supposed to eradicate all instances of discrimination and unfairness for students and education staff ${ }^{180}$.

\section{International Humanitarian Law}

Insecurity and armed conflict are a humanitarian challenges that influence the lives and safety of students and educational staff. If students' lives and safety are threatened, they cannot educate, and teachers will not be capable to provide students with education. Protecting students and educational staff is the most significant factor in helping support the right to education ${ }^{181}$. International humanitarian law forbids attacks by armed groups on civilians and population groups such as student and education staff, as seen for example in Article 13 (2) of Additional Protocol II: "The civilian population as such, as well as individual civilians, shall not be the object of attack. Acts or threats of violence the primary purpose of which is to spread terror among the civilian population are prohibited"182. Further, children under the age of 15 may not be not employed into the armed forces, and it should be stated that students may be in this group. Additional Protocol I Article 4(3)(c) addresses this subject as follows: "children who have not attained the age of fifteen years shall not be recruited into the armed forces or other armed groups, nor allowed to take part in hostilities"183.

Within the framework of the Special Protection of Humanitarian Law, protection of students and female education staff is covered by customary international law. Article 27 (2) of the Fourth Geneva Convention forbids rape and other abusive practices against females as follows: "Women shall be especially protected against any attack on their honor, in particular against rape, enforced prostitution or any form of indecent assault"184. Rape or sexual assault is forbidden by the Fourth Geneva Convention, Article 27, ${ }^{185}$ as well as by Additional Protocol I (Article 76) and Additional Protocol II (Article 4) and customary law applicable in international armed conflicts and noninternational armed conflicts"186. Thus, all parties to armed conflict must stop and forbid sexual violence, whether characterized as an education-associated form of violence or not ${ }^{187}$.

Articles 51 (1) and (3) of Additional Protocol I condemn deliberate and direct attacks against students and educational staff and define them as severe violations in these terms: "The civilian population and individual civilians shall enjoy general protection against dangers arising from military operations ... unless and for such time as they take a direct part in hostilities" 188 . This reveals that the students and education staff are fully protected unless they involve in armed hostility ${ }^{189}$.

Violations against students and education staff during armed international or non-international conflict are

\footnotetext{
178 Amnesty International, Torture and Ill-Treatment in the War on Terror, 2008

$<$ https://www.amnesty.org/en/documents/ACT40/014/2005/en/>.

${ }^{179}$ Article 2(1), International Covenant on Civil and Political Rights (ICCPR), 1966.

${ }^{180}$ Wendy Zeldin, 'Children's Rights: International Laws', 2007 <http://www.loc.gov/law/help/child-rights/international-law.php>.

${ }^{181}$ GCPEA, 'What Schools Can Do to Protect Education from Attack and Military Use', 2016, 9.

182 Article 13 (2), Additional Protocol II, 1977.

183 Article 4 (3) (c), Additional Protocol I, 1977.

184 Article 27 (2), The Fourth Geneva Convention, 1949.

${ }^{185}$ Minnesota Advocates for Human Rights, The case of sexual violation and rapes have emerged in the main Polish cities under the control of the Red Army during the end of the Second World War in Europe until the dissolution of the Soviet Union, In the age of emancipation Poland., 1945.

${ }^{186}$ ICRC, 'Sexual Violence in Armed Conflict: An Invisible Tragedy', $2013<$ https://www.icrc.org/ara/resources/documents/faq/sexualviolence-questions-and-answers.htm>.

${ }^{187}$ Gloria Gaggioli, 'Sexual Violence in Armed Conflicts: A Violation of International Humanitarian Law and Human Rights Law', International Review of the Red Cross, 96.894 (2015), $505<\mathrm{https}$ ://doi.org/10.1017/S1816383115000211>.

188 Article 51 (1) and (3), 'The Additional Protocol I', 1949.

189 European Commission, 'Special Education Needs Provision within Mainstream Education', $2018<\mathrm{https} / / /$ eacea.ec.europa.eu/nationalpolicies/eurydice/content/special-education-needs-provision-within-mainstream-education-77_en>.
} 
forbidden by international humanitarian law ${ }^{190}$. In agreement with the ban on the utilization of means of combat against students and education staff seen in the Rome Statute in Article 8, means of warfare are limited and the utilization of internationally forbidden weapons are described as war crimes by Article 8, Paragraph (b) (18), which prohibits the utilization of poisonous gas and all other harmful liquids, substances or devices. Article 8, Paragraph (b) (20), also considers the utilization of weapons, missiles, materials or techniques of warfare which by their very nature cause unfocused damage and / or unnecessary suffering as an offense against the International Law of Armed Conflict ${ }^{191}$. In sum, the provisions of international humanitarian rights law also ensure the right to life, the right not to be subject to deportation or forcible transfer, the right to be protected from unlawful murder and other rights discussed above.

\section{International Criminal Law}

The international community recognizes an crucial necessity to protect civilians, particularly women and children, from abuse during armed conflict. This resulted in the establishment of a permanent international criminal court to punish perpetrators of crimes against humanity at the demand of the General Assembly in $1989^{192}$. International criminal law does not offer distinctive support for education, but many of its provisions, such as those associated with persecution or incitement to genocide, may be utilized to protect education ${ }^{193}$. Many general rules of international criminal law relate to students and education personnel. For example, murder, torture, inhuman or degrading treatment, sexual violence, enforced recruitment, persecution and deportation all create severe violations of education ${ }^{194}$. In addition, Article 8(2) of the Rome Statute of the International Criminal Court forbids "(ii) Torture or inhuman treatment ...(iii) Willful causing of great suffering or serious injury to body or health and (iv) Extensive destruction and appropriation of property..." ${ }^{195}$.

The Rome Statute describes persecution as depriving part of a population or a whole population of their "fundamental rights" in violation of international law by reason of the "identity of the group"196. International criminal law has accepted murder, imprisonment, deportation, genocide and systematic discrimination against students and educational staff according to their "political, racial, national, sectarian, cultural, religious or gender identity" as crimes ${ }^{197}$. The International Criminal Tribunal for the Former Yugoslavia (ICTY) has ruled that the exclusion of individuals belonging to an ethnic or religious group from educational institutions could fall under the description of persecution. This may be utilized to guarantee "education in situations of insecurity and armed conflict". In Prosecutor v Tadic it was notes that "acts of a physical, economic or judicial nature that violate an individual's right to the equal enjoyment of his basic rights" 198 are forbidden. In customary international criminal law, persecution is restricted to political, religious and racial discrimination. Nonetheless, the Rome Statute spreads the scope of persecution to acts or omissions that distinguish according to nationality, culture or gender, and to "other grounds that are universally recognized as impermissible under international law"199.

International criminal law may be utilized to education-associated violations since behavior that is criminal under international criminal law can have a direct or indirect influence on children's right to education. Article 3(c) of the Genocide Convention revealed that the crime of "direct and public incitement to commit genocide" may include an implied protection of education, as pointed out in the framework of the Statute of the ICL, ICTR ${ }^{200}$ and

\footnotetext{
${ }^{190}$ Special Court for Sierra Leone Para.111, "sexual violence is broader than rape and includes such crimes as sexual mutilation, forced marriage, and forced abortion as well as the gender related crimes explicitly listed in the ICC Statute as war crimes and crimes against humanity, namely, 'rape, sexual slavery, enforced prostitution, forced pregnancy, enforced sterilisation' and other similar forms of violence".

191 Article 8, paragraph (b) (18) (b) (20), Rome Statute of the International Criminal Court, $1998<\mathrm{https}: / / \mathrm{www} . \mathrm{icc}-$ cpi.int/resourcelibrary/official-journal/rome-statute.aspx $>$.

192 General Assembly, Resolution 44/39 of December, 1989.

${ }^{193}$ Right to Education Initiative, 'Education in Emergencies', $2018<\mathrm{http}$ //www.right-to-education.org/ar/node/69>

194 Payam Akhavan, 'Reconciling Crimes Against Humanity with the Laws of War', 2008, 20-24; Leila Nadya Sadat, 'Crimes Against Humanity in the Modern Age', 2003, 355-56.

195 Articles 8(2)(a)(ii, Iii, Iv), The Rome Statute of the International Criminal Court, 1998.

${ }^{196}$ Art.7(2)(g), The Rome Statute of the International Criminal Court, 1998; Christine Byron, 'War Crimes and Crimes Against Humanity in the Rome Statute of the International Criminal Court', 2009, 123. <https://doi.org/10.7228/manchester/9780719073892.001.0001>.

${ }^{197}$ Article.7(1)(h), The Rome Statute of the International Criminal Court, 1998.

${ }^{198}$ Kristin Hausler, Nicole Urban, and Robert McCorquodale, 'Protecting Education in Insecurity and Armed Conflict: An International Law Handbook', British Institute of International and Comparative Law, 2012, 108 $<$ http://scholar.google.com/scholar?hl=en\&btnG=Search\&q=intitle:Protecting+Education+in+Insecurity+and+Armed+Conflict:+An+Interna tional+Law+Handbook\#0>; Prosecutor v Tadic, Trial Chamber Judgment, para.710, 1999.

199 Jessie Chella, 'Persecution: A Crime against Humanity in the Rome Statute of the International Criminal Court', $2004,145$.

${ }^{200} \operatorname{Art} .2(3)(\mathrm{c})$, ICTR Statute.
} 
ICTY 201 , as well as the Rome Statute ${ }^{202}$. The utilization of educational content such as "curricula, textbooks, and lessons to incite genocide" ${ }^{203}$ is considered in light of the Rome Statute to constitute an international crime, since it may be interpreted as "directly and publicly inciting others to commit genocide" 204 . It should be stated, however, that the crime of incitement to genocide has been thus far applied only to the public speeches of government officials or media campaigns and has not as yet been applied to educational materials and content ${ }^{205}$.

\section{Conclusion}

Children are not fully developed and need adults to ensure their security and care for their well-being. Children have psychological as well as physical and social needs, and one such need is for structured education in order to develop their potential and eventually become contributing members of society ${ }^{206}$. Accordingly, the international community should take the issue of children's education rights into consideration ${ }^{207}$.

International humanitarian law has made enormous strides and achieved many goals in the area of children's education rights. However, millions of children worldwide are still experiencing violation of their education rights. Child education rights are an integral part of human rights, and the development of human rights in general has led to a shift towards attention to children's educational rights. With the accession of 197 countries to the Universal Declaration of Human Rights, these rights may now be considered global. This has led to the recognition of all child rights, including education rights, as human rights ${ }^{208}$. Therefore, any matter that impedes the child's education and growth is forbidden ${ }^{209}$. During armed conflict, children are protected, for example by the Geneva Conventions in support of civilians and the Additional Protocol I. They are subject to the basic guarantees provided for in these treaties, in particular as regards the rights to education and life and the bans on coercion, physical punishment, retaliation, bullying and torture ${ }^{210}$.

This study has argued that international humanitarian law protects children's education rights during armed conflict, since the rules of IHL compliance apply to civilians, including children. Conflict situations threaten child rights, including the right to education, by the directing of state economies to war operations, and non-compliance with the rules of international humanitarian law applicable to the protection of rights of children during armed conflict is unfortunately a reality in many locations. Therefore, legal articles and international conventions must be backed by genuine commitment by states to their observance. Furthermore, it is necessary to have international oversight of compliance to bind countries and member states to the implementation of the education rights of children. International mechanisms and bodies are required to improve and reinforce protection and work towards fuller implementation.

\section{Recommendations}

Despite IHRL and IHL laws, millions of children continue to be innocent victims of conflict incidents. Existing rules and regulations in the form of provisions, conventions and treaties provide partial support to children involved in armed conflict but are not sufficient, particularly when some member states fail to support the education rights of children. As we continue to observe violations of the right to education of children in armed conflict, parties in conflict have the main duty for terminating these situations. Governments which are committed to ratifying children's education specific treaties and conventions in armed conflict must also carry out national measures in line with their legal systems to implement these treaties and conventions. There is a need for extensive awarenessraising efforts until all agree on the acceptance of humanitarian law dictates in order to ensure real action on children's education rights.

Recommendations of this investigation in support of the realization of the right to education of children in armed

\footnotetext{
${ }^{201}$ Art.4(3)(d), ICTY Statute, 1991; Hausler, Urban, and McCorquodale, p10.

${ }^{202}$ Leena Grover, 'A Call to Arms: Fundamental Dilemmas Confronting the Interpretation of Crimes in the Rome Statute of the International Criminal Court', European Journal of International Law, 21.3 (2010), 543-65 <https://doi.org/10.1093/ejil/chq057>.

${ }^{203}$ Initiative, p. 1.

${ }^{204}$ Article 25(3)(e), Rome Statute of the International Criminal Court, 1998.

${ }^{205}$ Prosecutor v Ruggiu ICTR Trial Chamber, 2000.

206 Dr Steevens' Hospital, 'Child Protection and Welfare Practice', Health Service Executive, 2011, 4 $<$ https://doi.org/http://www.hse.ie/eng/services/Publications/services/Children/WelfarePractice.pdf $>$.

${ }^{207}$ UNICEF, 'Protection and Promotion of the Rights of Children Working and/or Living on the Street', 2011, 9.

${ }^{208}$ United Nations Economic and others, Children and Armed Conflict: A Guide to International Humanitarian and Human Rights Law, The Effects of Brief Mindfulness Intervention on Acute Pain Experience: An Examination of Individual Difference (@) International Bureau for Children's Rights(IBCR), 2010), I, p. $187<$ https://doi.org/10.1017/CBO9781107415324.004>.

209 Dan O’Donnell and Dan Seymour, 'Child Protection: A Handbook for Parliamentarians', 2004, 52.

${ }^{210}$ ICRC, 'Basic Rules of the Geneva Conventions and Their Additional Protocols', 1988, 12; Icrc, 'Chidren in War', 2004, 30.
} 
conflict may be stated as follows:

1) Specific international conventions and education-relevant obligations are required to guarantee enforcement and bind countries or member states to implement the articles or provisions properly in order to improve and reinforce the education rights of children.

2) Awareness-raising efforts should be made in order to emphasize the importance of the right to education of children in times of peace and armed conflict.

3) Legal assistance for actors seeking the enforcement of education rights, whether through international jurisdiction or through professional claims in which civil society organizations contribute, should be provided for.

4) Measures and procedures to provide further guarantees for the realization of the right to education should be instigated.

5) The most logical means to support the protection of child education should be used in order to dramatically expand access to education in armed conflict.

6) State parties to the conventions and treaties should try to establish high-level security enforcement rules to protection children's education rights in armed conflict, and to oblige countries to comply with them and to deal with violators of children's education rights in armed conflict. Special courts should be established to prosecute and punish violators.

7) The Security Council should establish a Monitoring and Reporting Mechanism (MRM) to systematically monitor, document and report on grave violations committed against children's education rights in situations of armed conflict. 